\title{
COVER CROPS AND THEIR RELATIONSHIP WITH THE QUALITATIVE AND QUANTITATIVE ATTRIBUTES OF SOYBEANS
}

Alex Vinicius Bellinasso ${ }^{1}$, Ivan Ricardo Carvalho ${ }^{1}$, José Antonio Gonzalez da Silva ${ }^{1}$, Natã Balssan Moura ${ }^{1}$, Danieli Jacoboski Hutra ${ }^{1}$, Murilo Vieira Loro ${ }^{1}$, Valéria Escaio Bubans ${ }^{1}$, Francine Lautenchleger ${ }^{2}$

\footnotetext{
${ }^{1}$ Northwestern Regional University of the State of Rio Grande do Sul, Ijuí - Rio Grande do Sul State, Brazil E-mails: belina@gmail.com, carvalho.irc@gmail.com, silva@gmail.com, moura@gmail.com, hutra@gmail.com, lora@gmail.com,bubans@gmail.com, laute@gmail.com

${ }^{2}$ Midwestern State University (Unicentro), Guarapuava - Paraná State, Brazil

E-mail: laute@gmail.com
}

\begin{abstract}
The work aims to evaluate the effects of soil cover and soybean cultivars on the qualitative and quantitative attributes of soybeans. The experiment was conducted at Giruá, state of Rio Grande do Sul, Brazil. The experimental design was a randomized factorial block design, with two cover crops x seven soybean cultivars, disposed in three repetitions. Agricultural characteristics and nutritional attributes of soya were evaluated. The different coverings influenced the soybean performance for the main variables studied, grain yield was maximized in the coverage of Raphanus sativus + Avena strigosa for the cultivar DM 57152 IPRO, and the greenish grain levels were lower, consequently increasing the percentage of oil content for that same coverage. The components of variance and genetic parameters show that grain yield was influenced by $56 \%$ due to the effects of cultivars and $44 \%$ coming from the type of soil cover used.
\end{abstract}

Keywords: Glycine max, strategic position, nutrients, tissue, green grains

\section{COBERTURAS DO SOLO E SUAS RELAÇÕES COM OS ATRIBUTOS QUALITATIVOS E QUANTITATIVOS DOS GRÃOS DA SOJA}

\section{RESUMO}

O trabalho tem como objetivo avaliar os efeitos da cobertura do solo e de cultivares de soja sobre os atributos qualitativos e quantitativos da soja. O experimento foi conduzido em Giruá, estado do Rio Grande do Sul, Brasil, com delineamento experimental em blocos casualizados, com duas coberturas $\mathrm{x}$ sete cultivares de soja, dispostas em três repetições. Foram avaliados características agronômicas e atributos nutricionais da soja. As diferentes coberturas influenciaram 
no desempenho da soja para as principais variáveis estudadas, a produtividade de grãos foi maximizada na cobertura com Raphanus sativus + Avena strigosa para a cultivar DM 57I52 IPRO, e os teores de grãos esverdeados foram menores, consequentemente aumentando o percentual de teor de óleo para essa mesma cobertura. Os componentes de variância e os parâmetros genéticos mostram que a produtividade de grãos foi influenciada em $56 \%$ pelos efeitos das cultivares e $44 \%$ pela cobertura do solo utilizada.

Palavras-chave: Glycine max, posicionamento estratégico, nutrientes, tecido, grãos verdes

\section{INTRODUCTION}

Soybean (Glycine max L.) is the most grown legume in the world. The area sown in Brazil was 12 million hectares, $1.5 \%$ higher than the previous year, representing a record production estimated in 120.4 million tons, gain of $4.7 \%$ in relation to the $2018 / 2019$ crop season (CONAB, 2020). Its production is extremely important, as it is one of the main raw materials for animal and human food and biofuel production due to the high oil and protein content in the grains, in addition to being exported to different countries, the main one being China.

The crop may have different responses to the levels of fertility and water condition to which they are submitted. Allied to this, different agricultural practices are used, one of them is the succession of crops, which mainly aims at increasing productivity, in addition to providing a good straw, minimizing runoff from water, which results in considerable soil losses and fertility in areas with high slope, also contributes to a lower incidence of invasive plants, maintenance of humidity and improvement in soil organic matter indexes. Another cultivation practice is crop rotation, which aims to use different crops, aiming at improving soil quality such as nutrient cycling, soil microbiological activity and breaking the disease cycle (MÉDIÈNE et al., 2011).

Different crops can be used as soil cover, according to their specificity, some provide higher levels of dry matter, greater root development, which become factors that directly influence the subsequent crop, in addition to assisting in natural pest control and diseases. Among the cover crops, the use of Raphanus sativus, widely used as green manure, belongs to the cruciferous family, has rapid development and in about 60 days covers $70 \%$ of the soil. It stands out for its pivoting root system, reaching an average of $40 \mathrm{~cm}$. It produces a large amount of biomass (CIBOTTO et al., 2016). 
Another crop widely used for soil cover is Avena sativa, with good tillering. It has rapid growth and development, thus controlling the erosion and appearance of spontaneous plants (PEREIRA et al., 2011). These crops can be used as a consortium, in this case using Avena strigosa, due to its greater rusticity. The use of intercropped species results in a greater accumulation of nutrients, dry matter, greater exploitation of the soil due to different root systems (GIACOMINI et al., 2003). In this sense, the work aims to evaluate the effects of soil cover and soybean cultivars on the qualitative and quantitative attributes of soybeans.

\section{MATERIAL AND METHODS}

The experiment was conducted in Santo Antônio do Comandaizinho, municipaly of Giruá, Rio Grande do Sul State, Brazil, which is located at $28^{\circ} 10^{\prime} 75.6^{\prime \prime} \mathrm{S}, 54^{\circ} 30^{\prime} 25.9^{\prime \prime} \mathrm{W}$ and an altitude of 350 meters. The local soil is classified as a typical red dystrophic latosol (oxisol) (SANTOS et al., 2006), with a deep and well-drained profile of dark red color. The region climate is characterized as humid subtropical or Cfa, according to Köppen.

The experimental design used was a randomized factorial block design, with two cover crops: Avena sativa (AV) and Raphanus sativus + Avena strigosa (NA) x 7 soybean cultivars (DM 5958 RSF IPRO; FPS 1859RR; SRM 5951; C2570RR; M5838 IPRO; M5947 IPRO; DM 57152 IPRO), arranged in three repetitions. For phytosanitary management, four applications with fungicides were performed: two with Aproach prima ${ }^{\circledR}$ (Picoxystrobin $200 \mathrm{~g} \mathrm{~L}^{-1}$ and Ciproconazole $80 \mathrm{~g} \mathrm{~L}^{-1}$ ) and two of Fox ${ }^{\circledR}$ (Bixafen $125 \mathrm{~g} \mathrm{~L}^{-1}$, Protioconazole $175 \mathrm{~g} \mathrm{~L}^{-1}$, Trifloxystrobin $150 \mathrm{~g} \mathrm{~L}^{-1}$ ) and three applications with insecticides, two with Chloropyriphos ${ }^{\circledR}$ (Chloropyriphos $480 \mathrm{~g} \mathrm{~L}^{-1}$ ) and Cypermethrin ${ }^{\circledR}$ (Cypermethrin $250 \mathrm{~g} \mathrm{~L}^{-1}$ and Ciclosol $602.5 \mathrm{~g} \mathrm{~L}^{-1}$ ), and one with Abamex ${ }^{\circledR}$ (Abamectin $18 \mathrm{~g} \mathrm{~L}^{-1}$ ).

The sowing density was 226 thousand plants per hectare, the experimental units consisted of six meters in width and five in length, with 12 sowing lines with 0.5 meters of spacing between lines, and a useful area of $12 \mathrm{~m}^{2}$. The coverings of Avena sativa and Raphanus sativus + Avena strigosa were sown in the first half of May, the first at a density of $90 \mathrm{~kg} / \mathrm{ha}^{-1}$ and the second at a haul with a population density of $7 \mathrm{~kg} / \mathrm{ha}^{-1}$ and $30 \mathrm{~kg} / \mathrm{ha}^{-1}$ respectively, thus forming a mix of crops. The area sowing with soybean occurred on November 17, 2019, the leaf analysis was performed on March 10, 2020, and the harvest was performed on March 28, 2020. 
Evaluations of soybean cultivars were carried out by sampling five plants in each experimental unit. The variables being analyzed in the field, first pod insertion height (FI, cm); plant height $(\mathrm{PH}, \mathrm{cm})$; number of pods on the main stem (MS, unit); number of pods on the branches (NPB, unit); number of branches (NB, unit); number of pods with one grain (PO, unit); number of pods with two grains (PTW, unit); number of pods with three grains (PTH, unit), number of grains per plant (GP), thousand grain mass (TG - unit), plant grain mass (GM/kg ha $\left.{ }^{-1}\right)$, number of green grains (GR, unit), total grain yield $\left(\mathrm{GY} \mathrm{kg} \mathrm{ha}{ }^{-1}\right)$ with correction for $13 \%$ moisture.

The variables evaluated in the tissues were verified from the analysis of the grains by Near Infrared Spectroscopy (NIRS) being the following: stearic acid (ES\%); linoleic acid (NO\%), linolenic acid (NC\%), oleic acid (LE\%), palmitic acid (PM\%), total calcium (AT\%), total carbohydrates ( $\mathrm{CH} \%)$, sulfur (ST\%), grain crude fiber (FG), acid detergent fiber (FT\%), neutral detergent fiber (DN\%), total phosphorus (PT\%), total lipids (LIGT\%), total magnesium (GT\%), mineral matter in the grain ( MM\%), mineral material (MT,\%), total oil (OT\%), total oil in the grain (OG\%), total potassium (KT\%), total protein (NT\%) and total grain protein (PG\%) .

The data obtained were subjected to assumptions of the statistical model, these being normality and homogeneity of the residual variances, as well as the additivity of the model, after the analysis of variance was performed at $5 \%$ probability in order to identify the interaction between the soil coverage soil $x$ soybean cultivars, the significant interactions were broken down to simple effects, basing their probability by the Tukey matrix. In contrast, the characters that did not differ in terms of interaction were broken down to the main effects through complementary analyzes by the Duncan test at $5 \%$ probability.

In order to identify the determining variables for green grains, grain yield, crude protein and oil in the grains, a multiple regression model was applied, with stepwise criteria, it is an automatic tool used in the exploratory stages of model construction to identify a useful subset of predictors. The process systematically adds the most significant variable or removes the least significant variable during each step. With significance based on the $\mathrm{T}$ test at $5 \%$ probability, using the formula: $\mathrm{y}=\mathrm{b} 0+\mathrm{b} 1 \mathrm{x} 1+\mathrm{b} 2 \mathrm{x} 2+\ldots .+\mathrm{Bk}+\mathrm{Xk}$ : Where $\mathrm{y}=$ Dependent variable, $\mathrm{x} 1, \mathrm{x} 2$ and $\mathrm{xk}=$ known variables on which to base the predictions, b0, b1, b2: numerical constants to be determined from the observed data.

Due to the need to understand the causes and effects of the sources of variation in the expression of characters of agronomic importance, deviance analysis at $5 \%$ probability by the $\mathrm{x}^{2}$ 
matrix was used, the characters that showed the maximum likelihood ratio (LRT), significant provided the estimates of the variation components and genetic parameters, these parameters were estimated using models based on the restricted maximum likelihood (REML), using the statistical model: $y=X r+Z g+W i+e$ where $\mathrm{y}=$ vector of the data, $\mathrm{r}=$ effect of repetitions (fixed), $\mathrm{g}=$ are the phenotypic effects (random), $\mathrm{i}=$ are the effects of the genotypes $\mathrm{x}$ environment interaction (random), $\mathrm{e}=$ are the residues (random). Subsequently, genotypic variance $\left(\sigma^{2} G\right)$, genotype $\mathrm{x}$ environment interaction variance $\left(\sigma^{2} I N T\right)$, residual variance $\left(\sigma^{2} E\right)$, individual phenotypic variance $\left(\left(\sigma^{2} P\right)\right.$, broad sense heritability for the total genotypic effects $\left(\widehat{H}^{2} g\right)$, mean heritability of the genotype $\left(\widehat{H}^{2} \mathrm{mg}\right)$, accuracy for the selection of the genotypes $(\check{r} g \breve{g})$, coefficient of determination of the effects of the genotype $\mathrm{x}$ environment interaction $\left(C^{2} I N T\right)$, genotypic correlation between the performance of environments $(\check{r}$ gloc), coefficient of genotypic variation $(\mathrm{CVg})$, residual coefficient of variation $(\mathrm{CVe})$ and the general average.

Due to the large number of characters measured in this research, the multivariate method was used to estimate the main components BIPLOT. This method was developed by Gabriel (1971) to graphically represent results of principal component analysis or singular value decomposition, in which the value of each element of a double entry table can be visualized by the product of vectors and the cosine of the angle between two vectors (YAN \& KANG, 2003). This nature provided that factors of variation and variables were present concurrently in the Cartesian plane.

\section{RESULTS AND DISCUSSION}

The pluviometric indexes (Figure 1) for this crop season were atypical, when compared to previous years, with this it was possible to evaluate the effect of the cover that showed greater efficiency, in the quality of the grain and in the level of greenish grains, in different soybean cultivars.

During the conduction of the experiment, the accumulated precipitation was $414 \mathrm{~mm}$, with a water deficit of 36 days during the cycle. At the beginning of soy development, this stress can reduce emissions from new branches, reducing the potential number of nodes that could produce pods. According to Escalera et al., (2019) the water deficit is one of the limiting factors of agriculture, affecting the performance of soybeans and the quality of grains. 


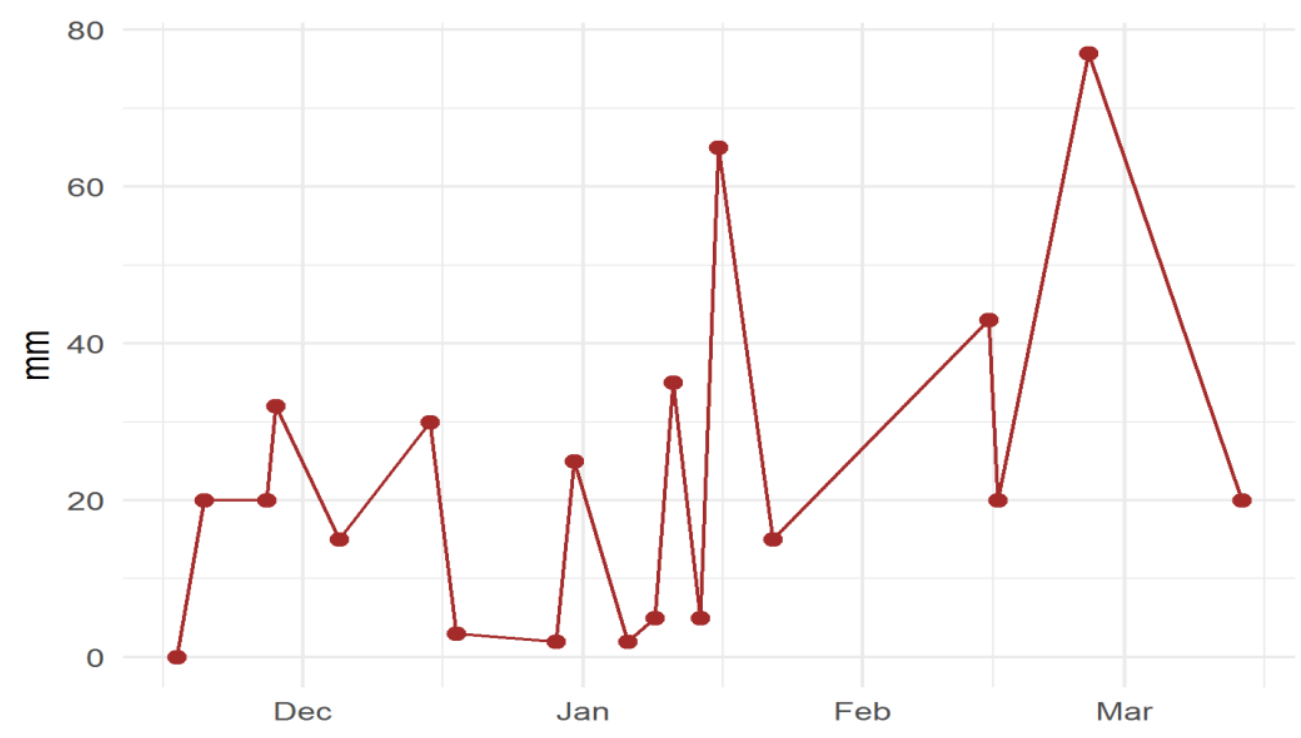

Figure 1. Rainfall index in the county of Giruá, Rio Grande do Sul State, Brazil, over the period of implementation of the experiments.

This deficiency occurs when the rate of water absorption exceeds the rate of transpiration, numerous physiological characteristics are altered in plants under stress conditions, including efficient water use, leaf water potential, stomatal properties and leaf temperature (TAVARES et al., 2013). In addition to physiological changes, there is a reduction in biomass production, grain yield, in addition to changing the chemical and nutritional composition. The magnitude of the changes depends on the duration and intensity of the stress, the genetic material and the stage of development of the plant (FOLLMANN et al., 2016). The results obtained through the analysis of variance (Table 1) for interaction between soil cover and cultivars for the variables analyzed in the experiment, where it presents significance at $5 \%$ probability for interaction between soil cover and cultivars for the following variables are: First pod insertion height (FI), Number of branches (NB), Number of pods on the main stem (MS), Number of pods on the branches (NPB), Number of pods with three grains (PTH), Number of grains per plant (GP) Grain mass per plant (GM) Number of pods per plant (PP), Thousand grain mass (TG), Total grain yield (GY), Number of green grains (GR), Total grain protein (PG ) and total oil in the grain (OG). The variables that showed significance only for coverage were: Plant height (PH), Number of pods with two grains (PTW), Crude grain fiber (FG). And for the cultivar factor: Plant height (PH), Number of pods with one grain (PO), Number of pods with two grains (PTW), Number of pods with four (PF) and Crude fiber in the grain (FG). 
Table 1. Analysis of variance for the effects of soil cover and soybean cultivars at $5 \%$ probability. Giruá, Rio Grande do Sul State, Brazil.

\begin{tabular}{|c|c|c|c|c|c|c|c|c|c|c|c|c|c|}
\hline \multirow{2}{*}{ SV } & \multirow{2}{*}{ DF } & \multicolumn{12}{|c|}{ MEAN SQUARES } \\
\hline & & FI & $\mathbf{P H}$ & NB & MS & NPB & PO & PTW & PTH & GP & PF & GM & $\mathbf{P P}$ \\
\hline $\begin{array}{c}\text { Coverage } \\
\text { (CO) }\end{array}$ & 1 & 17,43 & $792,68 *$ & 1,38 & $515,43^{*}$ & 24,68 & 14,73 & $\begin{array}{l}154,925 \\
*\end{array}$ & 40,91 & $4.212,64$ & 0,29 & 70,86 & $1015,99 *$ \\
\hline Cultivar (C) & 6 & $802,42 *$ & $7340,20 *$ & $352,45^{*}$ & $\begin{array}{l}1227,32 \\
*\end{array}$ & $\begin{array}{l}29599,19 \\
*\end{array}$ & $\begin{array}{l}125,13 \\
*\end{array}$ & $\begin{array}{l}1878,05 \\
*\end{array}$ & $\begin{array}{l}13086,00 \\
*\end{array}$ & $\begin{array}{l}165082,43 \\
*\end{array}$ & $\begin{array}{l}29,38 \\
*\end{array}$ & $\begin{array}{l}2353,60 \\
*\end{array}$ & $\begin{array}{l}24459,93 \\
*\end{array}$ \\
\hline $\mathrm{CO} \times \mathrm{C}$ & 6 & $298,57 *$ & 107,25 & $28,72 *$ & $\begin{array}{l}1698,86 \\
*\end{array}$ & $1787,64 *$ & 17,73 & 413,58 & $3183,18 *$ & $39651,29 *$ & 5,61 & $487,21 *$ & $5158,29 *$ \\
\hline Block & 2 & 37,26 & $490,98 *$ & $10,18^{*}$ & 102,07 & 529,49 & 21,53 & 186,83 & 403,20 & $2.810,63$ & 2,21 & 85,69 & 400,01 \\
\hline Residue & $\begin{array}{c}19 \\
4\end{array}$ & 11,48 & 22,26 & 1,92 & 63,43 & 108,65 & 5,32 & 34,94 & 88,53 & $1.217,29$ & 0,61 & 21,99 & 199,49 \\
\hline $\mathrm{CV}$ & & 18,83 & 5,83 & 58,05 & 21,46 & 77,68 & 86,78 & 34,78 & 32,42 & 27,55 & $\begin{array}{l}151,4 \\
8\end{array}$ & 32,09 & 28,02 \\
\hline \multirow[t]{2}{*}{$\mathrm{R}^{2}$} & & 0,30 & 0,67 & 0,62 & 0,22 & 0,60 & 0,15 & 0,28 & 0,50 & 0,48 & 0,24 & 0,42 & 0,45 \\
\hline & & \multicolumn{12}{|c|}{ MEAN SQUARES } \\
\hline SV & DF & TG & GY & GR & PG & OG & FG & MM & PM & ES & $\mathbf{L E}$ & NO & $\mathbf{N C}$ \\
\hline $\begin{array}{c}\text { Coverage } \\
\text { (CO) }\end{array}$ & 1 & 251,61 & $6749083,8^{*}$ & $743,14 *$ & $1,54 *$ & 1,10 & $0,14 *$ & 0,00 & 0,82 & 0,02 & 2,60 & 0,50 & 1,72 \\
\hline Cultivar (C) & 6 & $\begin{array}{c}16384,71 \\
*\end{array}$ & $57603611,9 *$ & $\begin{array}{l}6113,85 \\
*\end{array}$ & $31,93 *$ & 3,79 & $0,29 *$ & $0,18^{*}$ & $10,08 *$ & $0,71 *$ & $\begin{array}{l}85,66 \\
*\end{array}$ & $117,07 *$ & $5,02 *$ \\
\hline $\mathrm{CO} \times \mathrm{C}$ & 6 & 1659,40 & $\begin{array}{c}36972866,22 \\
*\end{array}$ & $\begin{array}{l}2257,85 \\
*\end{array}$ & 1,55 & $5,5301 *$ & 0,08 & 0,00 & 2,76 & 0,03 & 5,33 & 8,38 & 1,11 \\
\hline Block & 2 & 462,23 & 3950603,76 & 21,21 & 0,06 & 0,00 & 0,00 & 0,00 & 0,08 & 0,00 & 1,85 & 1,65 & 0,11 \\
\hline Residue & $\begin{array}{c}19 \\
4\end{array}$ & 257,29 & 961017,70 & 46,93 & 0,17 & 0,24 & 0,02 & 0,00 & 0,26 & 0,01 & 1,01 & 0,58 & 0,59 \\
\hline $\mathrm{CV}$ & & 13,90 & 27,70 & 15,89 & 1,07 & 2,33 & 2,41 & 0,34 & 4,61 & 1,62 & 3,92 & 1,40 & 15,15 \\
\hline $\mathrm{R}^{2}$ & & 0,27 & 0,36 & 0,83 & 0,94 & 0,77 & 0,71 & 0,98 & 0,80 & 0,92 & 0,88 & 0,94 & 0,83 \\
\hline
\end{tabular}

Source of variation (SV), Degree of freedom (DF), Coefficient of variation (CV), Determination coefficient $\left(\mathrm{R}^{2}\right)$, First pod insertion height (FI), Plant height (PH), Number of branches (NB ), Number of pods on the main stem (MS), Number of pods on the branches (NPB), Number of pods with three grains (PTH), Number of grains per plant (GP), Grain mass per plant (GM), Number of pods per plant (PP), thousand grain mass (TG), total grain yield (GY), number of green grains (GR), total grain protein (PG), total oil in the grain (OG); Number of pods with two grains (PTW), Crude fiber of the grain (FG), Number of pods with one grain (PO), Number of pods with four grains (PF), Mineral matter in grain (MM), Palmitic acid (PM), Stearic acid (ES), Oleic acid (LE), Linoleic acid (NO), Linolenic acid (NC). 
The analysis of the averages for the interactions between the cultivars and the coverings of Avena sativa (AV) and Raphanus sativus + Avena strigosa (AN) (Table 2) where that for the coverage of Avena sativa (AV) presented better results for the cultivar DM 57125 IPRO in number of pods with three grains (50.31); number of grains per plant (197.95); number of branches (4.06); grain yield (5037.84). The cultivar M 5838 IPRO stood out among the others for the number of pods on the main stem (38.80). The cultivar DM 5958RSF IPRO showed best results for the grain yield variable (4014.33).

According to Szareski et al., (2018), the choice of cultivar and sowing time may imply differences in plant heights and the first pod insertion, directly interfering in the mechanized harvesting operation. The superior results were observed in the coverage with Raphanus sativus + Avena strigosa (NA), in the cultivar FPF 1859 RR $(45,26)$ regarding the number of pods on the main stem. The cultivar DM 57152 IPRO regarding the number of branches (4.06), grain yield (5167.80), number of grains per plant (192.11). For the first pod insertion, the cultivar with the lowest average was M5838 IPRO (13.80), and the best coverage was AV (17.13). For the number of branches (NB) the cultivar that stood out was DM 57I52 IPRO. Presenting superior averages for both the coverage of Avena sativa and Raphanus sativus + Avena strigosa (NA), for the last coverage, it presented a lower average with the cultivar C $2570 \mathrm{RR}$.

The number of branches is one of the morphological characters that directly affects the leaf area index (LAI), influencing productivity, which can contribute on average with $16 \%$ of this index. But it can vary from $3 \%$ to $46 \%$ depending on the cultivar, season and sowing density (ZANON et al., 2018). For the number of pods on the main stem, on the cover Avena sativa (AV), there was no difference between the cultivars, and on the cover with Raphanus sativus + Avena strigosa the cultivar SPF 1859 RR was higher. For the number of pods with three grains, the cultivar DM 57152 IPRO showed a higher average for both coverings. In the number of pods per plant (PP) the cultivar that stood out in both coverings was DM 57152 IPRO. The cover that showed the lowest average was Avena sativa and showed little difference in two cultivars. For the number of grains per plant (GP), the cultivar that showed the highest average was the cultivar DM 57152 IPRO for both coverings. 
Table 2. Interactions between Avena sativa (AV) and Raphanus sativus + Avena strigosa (NA) coverings for different cultivars. Giruá, Rio Grande do Sul State, Brazil.

\begin{tabular}{|c|c|c|c|c|c|c|c|c|c|c|}
\hline \multirow[b]{2}{*}{ Cultivars } & \multicolumn{2}{|c|}{ FI } & \multicolumn{2}{|c|}{ NB } & \multicolumn{2}{|c|}{ MS } & \multicolumn{2}{|c|}{ PTH } & \multicolumn{2}{|c|}{$\mathbf{P P}$} \\
\hline & $\mathbf{A V}$ & NA & AV & NA & AV & NA & $\mathbf{A V}$ & NA & AV & NA \\
\hline FPS $1859 \mathrm{RR}$ & $18.46 \mathrm{aA}$ & $16.40 \mathrm{bcdA}$ & $0,06 \mathrm{cA}$ & $0,46 \mathrm{cA}$ & $32,46 \mathrm{aB}$ & $45.26 \mathrm{aA}$ & $16.60 \mathrm{dA}$ & $25.60 \mathrm{bA}$ & $32.67 \mathrm{bB}$ & $47.93 \mathrm{bA}$ \\
\hline SRM 5951 & $16,66 \mathrm{aA}$ & $14,80 \mathrm{cdA}$ & $1,26 \mathrm{bcA}$ & $2,26 \mathrm{bA}$ & $32.20 \mathrm{aB}$ & $41.53 \mathrm{abA}$ & $18.40 \mathrm{cdB}$ & 31.06abA & $39.93 \mathrm{bB}$ & $58.73 \mathrm{abA}$ \\
\hline C2570 RR & $20.06 \mathrm{aA}$ & $22,90 \mathrm{aA}$ & $2,60 \mathrm{aAb}$ & $1,40 \mathrm{bcB}$ & $35.40 \mathrm{aA}$ & $31.53 \mathrm{bA}$ & $32.40 \mathrm{bcA}$ & $22.13 \mathrm{bA}$ & $52.80 \mathrm{bA}$ & $40.53 \mathrm{bA}$ \\
\hline DM 5958 RSF IPRO & $19,40 \mathrm{aA}$ & $20,40 \mathrm{aAb}$ & $2,60 \mathrm{aAb}$ & $1,13 \mathrm{bA}$ & $34.00 \mathrm{aA}$ & $35.06 \mathrm{abA}$ & $35.46 \mathrm{abA}$ & $31.26 \mathrm{abA}$ & $51.93 \mathrm{bA}$ & $47.20 \mathrm{bA}$ \\
\hline M5947IPRO & $19,66 \mathrm{aA}$ & $16,66 \mathrm{bcdB}$ & $0,46 \mathrm{cA}$ & $0,33 \mathrm{cA}$ & $38.73 \mathrm{aA}$ & $43.73 \mathrm{aA}$ & $18.33 \mathrm{cdA}$ & $23.73 \mathrm{bA}$ & $40.66 \mathrm{bA}$ & $44.66 \mathrm{bA}$ \\
\hline DM 57I52 IPRO & $16,73 \mathrm{aA}$ & $19,26 a A b c$ & $4,06 \mathrm{aA}$ & $4,86 \mathrm{aA}$ & $37.26 \mathrm{aA}$ & $36.46 \mathrm{abA}$ & $50.31 \mathrm{aA}$ & $42.17 \mathrm{aA}$ & $74.88 \mathrm{aA}$ & $79.56 \mathrm{aA}$ \\
\hline \multirow[t]{2}{*}{ M5838 IPRO } & $17,13 \mathrm{aA}$ & $13,80 \mathrm{~dB}$ & $1,53 \mathrm{bcA}$ & $2,26 \mathrm{bA}$ & $38.80 \mathrm{aA}$ & $37.20 \mathrm{abA}$ & $30.93 \mathrm{bcdA}$ & $31.46 \mathrm{aBA}$ & $47.33 \mathrm{bA}$ & $51.80 \mathrm{bA}$ \\
\hline & \multicolumn{2}{|c|}{ GP } & \multicolumn{2}{|c|}{ GY } & \multicolumn{4}{|c|}{ GR } & \multicolumn{2}{|c|}{ OG } \\
\hline Cultivars & $\mathbf{A V}$ & NA & $\mathbf{A V}$ & NA & \multicolumn{2}{|c|}{$\mathbf{A V}$} & \multicolumn{2}{|c|}{ NA } & $\mathbf{A V}$ & NA \\
\hline FPS 1859 RR & $79.93 \mathrm{bB}$ & $120.33 \mathrm{bA}$ & $2493.85 b B$ & 3838.30abA & \multicolumn{2}{|c|}{$50.66 \mathrm{bA}$} & \multicolumn{2}{|c|}{$26.66 \mathrm{cdB}$} & $20.02 \mathrm{bB}$ & $21.89 \mathrm{aA}$ \\
\hline SRM 5951 & $94.80 \mathrm{bB}$ & 144.13abA & $2486.36 \mathrm{bB}$ & $3738.43 \mathrm{abA}$ & \multicolumn{2}{|c|}{$52.00 \mathrm{abA}$} & \multicolumn{2}{|c|}{$44.16 \mathrm{abA}$} & $20.64 \mathrm{bB}$ & $21.28 \mathrm{abA}$ \\
\hline C2570 RR & $136.26 \mathrm{bA}$ & $100.73 \mathrm{bA}$ & $3750.46 \mathrm{abA}$ & $2869.57 \mathrm{bA}$ & \multicolumn{2}{|c|}{$66.00 \mathrm{aA}$} & \multicolumn{2}{|c|}{$56.83 \mathrm{aA}$} & $20.53 \mathrm{bB}$ & $21.15 \mathrm{abA}$ \\
\hline DM 5958 RSF IPRO & $136.60 \mathrm{bA}$ & $123.06 \mathrm{bA}$ & $4014.33 \mathrm{abA}$ & $3707.41 \mathrm{abA}$ & \multicolumn{2}{|c|}{$34.83 \mathrm{cA}$} & \multicolumn{2}{|c|}{$38.83 \mathrm{bcA}$} & $20.68 b B$ & $21.57 \mathrm{abA}$ \\
\hline M5947IPRO & $93.73 \mathrm{bA}$ & $111.46 \mathrm{bA}$ & $3104.73 \mathrm{bA}$ & 3823.93abA & \multicolumn{2}{|c|}{$39.16 \mathrm{bcA}$} & \multicolumn{2}{|c|}{$15.66 \mathrm{~dB}$} & $20.60 \mathrm{bA}$ & $20.77 \mathrm{bA}$ \\
\hline DM 57I52 IPRO & $197.95 \mathrm{aA}$ & $192.11 \mathrm{aA}$ & $5039.84 \mathrm{aA}$ & $5167.80 \mathrm{aA}$ & \multicolumn{2}{|c|}{$34.83 \mathrm{cB}$} & \multicolumn{2}{|c|}{ 49.00abA } & $22.26 \mathrm{aA}$ & $20.75 b B$ \\
\hline M5838 IPRO & $125.26 \mathrm{bA}$ & $131.66 \mathrm{bA}$ & $3348.77 \mathrm{bA}$ & $3592 \mathrm{abA}$ & \multicolumn{2}{|c|}{$52.33 \mathrm{abA}$} & \multicolumn{2}{|c|}{ 45.33abA } & $21.84 \mathrm{aA}$ & $21.80 \mathrm{aA}$ \\
\hline
\end{tabular}

Lower case letters compare the cultivars within each covering in the column. * Capital letters compare the coverings for each cultivar in the row. * Averages followed by the same letter do not differ at $5 \%$ probability. First pod insertion height (FI), Number of branches (NB), Number of pods on the main stem (MS), Number of pods with three grains (PTH), Number of pods per plant (PP), Number of grains per plant (GP), Total grain yield (GY), Number of green grains (GR) and Total oil in grain (OG). 
Related to the other yield components, the number of pods per plant shows the least variation between different growing situations. Regarding coverage, Avena sativa only differed for two cultivars (FPS 1859 RR and SRM 5951). The number of pods per plant is determined by the balance between the number of flowers per plant and the percentage that develops until pods form (CARVALHO, NARDINO \& SOUZA, 2017). For grain yield (GY) the cultivar that presented the highest average was DM 57 I52 IPRO in the cover of Avena sativa. Grain yield becomes the main component to be pursued in order to reach ever higher levels of productivity, which has a direct influence on the income of rural producers. But a factor that has weight in determining it, are the climatic conditions, that when well distributed and with temperatures within the optimum condition for the crop and well distributed rainfall, the crop tends to express a good yield.

In the Raphanus sativus + Avena strigosa cover, better results were found in the cultivar DM 57152 IPRO, for a lower index of greenish grains (GR) and total oil (OT), however, a lower oil index in the grain (OG). It showed even better performance for not greening grains in the cultivars FPS 1859 RR, DM 5958 RSF IPRO and M 5947IPRO. For the same variable (OT) the highest averages were found in cultivars M 5947 IPRO, DM 57 I52 IPRO, M 5838 IPRO in the Avena sativa cover. The presence of green grains affects the quality of soy derivatives, which can reduce the oil content by up to $3 \%$ compared to mature grains, increasing the costs of the oil refining process and the production of protein products due to the presence of chlorophyll in addition to reducing the physiological quality of seeds (STROBEL et al., 2016).

The occurrence in the plant depends on the positioning of the pods and related to the response of the different soybean genotypes when subjected to water and thermal stress conditions (ARRUDA et al., 2017). This problem is related to the occurrence of drought in the last crop season, associated with high temperatures in the grain filling and pre-harvest phases. The removal of greenish grains can be performed by color-selecting equipment, which, although expensive, removes a large part of these grains (FRANCE NETO, 2012). According to a study carried out by Cibotto et al. (2016), the cover crops have an effect on the performance of the soybean crop due to the different amounts of biomass, nutrients left for the next crop, thermal regulation of the soil, levels of evapotranspiration and levels of organic matter.

The results of the averages test for mineral matter in the grain (MM), palmitic acid (PM), stearic acid (ES), oleic acid (LE), linoleic acid (NO), thousand grain mass (TG), number of pods with 4 grains (PF), number of pods with two grains (PTW) and number of pods with one grain 
(PO) were registered (Table 3). Where the levels of protein in grains and linoleic acid were higher for cultivars FPS 1859 RR (PG-39.99) (NO-57.06), SRM 5951 (PG-39.99) (NO-57.31), as well as the C2570 RR stood out in this variable (NO-56.32), and in the mineral matter in the grain, respectively (MM-5.33). Palmitic acid had the best average in the cultivars M5947 IPRO (PM11.93) and M 5838 IPRO (PM-11.56), as well as in stearic acid (ES-4.74), and DM 5958 RSF IPRO (ES-4.70), which also stood out in the oleic acid variable (LE-29.16) (Table 1).

Table 3. Average results for the soybean quality characters. Giruá, Rio Grande do Sul State, Brazil.

\begin{tabular}{llllllllllll}
\hline CULTIVARS & PG & MM & PM & ES & LE & NO & NC & TG & PF & PTW & PO \\
\hline FPS 1859 RR & $39,99^{\mathrm{a}}$ & $5,25 \mathrm{~b}$ & $10,10 \mathrm{~d}$ & $4,32 \mathrm{c}$ & $25,08 \mathrm{bc}$ & $57,06 \mathrm{a}$ & $3,84 \mathrm{~b}$ & $121,03 \mathrm{~b}$ & $0,37 \mathrm{bc}$ & $16,20 \mathrm{bcd}$ & $2,43 \mathrm{bc}$ \\
SRM 5951 & $39,99^{\mathrm{a}}$ & $5,245 \mathrm{bc}$ & $10,34 \mathrm{~cd}$ & $4,37 \mathrm{c}$ & $25,56 \mathrm{bc}$ & $57,31 \mathrm{a}$ & $3,16 \mathrm{~b}$ & $130,16 \mathrm{a}$ & $0,55 \mathrm{~b}$ & $17,10 \mathrm{bc}$ & $3,03 \mathrm{ab}$ \\
C2570 RR & $39,69 \mathrm{ab}$ & $5,33 \mathrm{a}$ & $10,92 \mathrm{bc}$ & $4,34 \mathrm{c}$ & $23,43 \mathrm{~d}$ & $56,32 \mathrm{a}$ & $5,92 \mathrm{a}$ & $99,82 \mathrm{~d}$ & $0,53 \mathrm{~b}$ & $18,83 \mathrm{~b}$ & $3,93 \mathrm{a}$ \\
DM 5958 RSF IPRO & $39,08 \mathrm{~b}$ & $5,19 \mathrm{~d}$ & $11,17 \mathrm{ab}$ & $4,70^{\mathrm{a}}$ & $29,16 \mathrm{a}$ & $52,00 \mathrm{c}$ & $3,80 \mathrm{~b}$ & $118,63 \mathrm{~b}$ & $1,24 \mathrm{a}$ & $23,14 \mathrm{a}$ & $3,10 \mathrm{ab}$ \\
M5947IPRO & $37,66 \mathrm{c}$ & $5,1 \mathrm{e}$ & $11,93 \mathrm{a}$ & $4,56 \mathrm{~b}$ & $25,40 \mathrm{bc}$ & $53,12 \mathrm{c}$ & $5,48 \mathrm{a}$ & $115,61 \mathrm{bc}$ & $0,10 \mathrm{c}$ & $14,06 \mathrm{~cd}$ & $1,20 \mathrm{c}$ \\
DM 57I52 IPRO & $37,66 \mathrm{c}$ & $5,22 \mathrm{c}$ & $11,28 \mathrm{ab}$ & $4,58 \mathrm{~b}$ & $24,00 \mathrm{~cd}$ & $54,54 \mathrm{~b}$ & $5,82 \mathrm{a}$ & $109,42 \mathrm{c}$ & $0,76 \mathrm{~b}$ & $13,37 \mathrm{~d}$ & $2,41 \mathrm{bc}$ \\
M5838 IPRO & $37,50 \mathrm{c}$ & $5,08 \mathrm{e}$ & $11,56 \mathrm{a}$ & $4,74 \mathrm{a}$ & $26,66 \mathrm{~b}$ & $52,6 \mathrm{~b}$ & $5,22 \mathrm{a}$ & $112,71 \mathrm{c}$ & $0,06 \mathrm{c}$ & $16,53 \mathrm{bcd}$ & $2,51 \mathrm{~b}$ \\
\hline
\end{tabular}

Means followed by the same lowercase letter do not differ at 5\% probability. Protein in grains (PG), Mineral matter in grains (MM), Palmitic acid (PM), Stearic acid (ES), Oleic acid (LE), Linoleic acid (NO), Linolenic acid (NC) Thousand grain mass (TG), Number of pods with four grains (PF), Number of pods with two grains (PTW), Number of pods with one grain (PO).

Related to the mineral material in the grain, the cultivar SRM 5951 presented an average corresponding to 130.16 . As for the number of pods with four grains, only the cultivar DM 5958 RSF IPRO (1.24) had significant values. In the variables number of pods with two and one grain, the cultivars DM 5958 RSF IPRO (23.14) and C2570 RR (3.93), were the ones with the highest averages.

The bromatological components need more detailed studies due to various interactions with the environment, according to Ferreira et al., (2019) these factors have a strong influence by the acidity of the soil, cultural management in the field, and inoculations carried out at planting, also as water offer in the reproductive period. Table 4 presents the average results for plant height and crude fiber, with cultivar M5947 IPRO showing the best result for plant height (PH), and the cultivars C2570 RR (5,54), FPS 1859 RR and DM 5958 RSF IPRO (5.36) for crude fiber, 
respectively. Several factors can influence plant height, Meira et al. (2016), highlight the plant stand, sowing time, fertility, humidity and the photoperiod.

Table 4. Average results per cultivar for the variables plant height and crude fiber. Giruá, Rio Grande do Sul State, Brazil.

\begin{tabular}{lll}
\hline CULTIVAR & PH & FB \\
\hline M5947IPRO & $94.43 \mathrm{a}$ & $5.32 \mathrm{~b}$ \\
DM 57I52 IPRO & $81.63 \mathrm{~b}$ & $5.24 \mathrm{~b}$ \\
DM 5958 RSF IPRO & $80.60 \mathrm{~b}$ & $5.36 \mathrm{ab}$ \\
SRM 5951 & $79.60 \mathrm{bc}$ & $5.22 \mathrm{~b}$ \\
C2570 RR & $78.00 \mathrm{~cd}$ & $5.54 \mathrm{a}$ \\
FPS 1859 RR & $76,53 \mathrm{de}$ & $5.36 \mathrm{ab}$ \\
M5838 IPRO & $75,26 \mathrm{e}$ & $5.24 \mathrm{~b}$ \\
\hline COBERTURA & AP & FB \\
Avena sativa & $78,92 \mathrm{~b}$ & $5,40 \mathrm{a}$ \\
Raphanus sativus + Avena strigosa & $82,80 \mathrm{a}$ & $5,25 \mathrm{~b}$ \\
\hline
\end{tabular}

Averages followed by the same lowercase letter do not differ at 5\% probability. Plant height (PH), Crude fiber (FB).

The relationship between the evaluated characters and the determinant predictors (Table 5), in the character number of green/greenish grains, was found to have a higher determination of MM (46.4559), as well as, in MT (36.0280), PG (0.0993) and PO (4.3489) and CH (23.9290). The grain mass variable per plant (264.42) was directly related to grain yield. The determinants for total protein in the grains were the variables, KT (5.5797), IG (3.2442), OT (2.1973), FG (0.1071) and PP (0.0198). Relevant to the total oils in the grains, it was found that the variables OT (3.7017), KT (2.5676), FT (0.3222), PF (0.1329) and PTW (0.0475) were determinants in the results obtained. Works produced by Pípolo (2002) report that the levels of oil and protein in soybeans are genetically defined, but influenced by the environment, especially during the grain filling period. The protein content in the grains is four times more dependent on environmental conditions than on the cultivar. Another study by Albrecht et al. (2008), reports the difference between the genotypes, regarding the metabolic regulation that determines the synthesis of proteins and oil, and that can affect other macromolecules, probably extending the influence on the synthesis of several other compounds, primary or secondary. 
Table 5. Predictive and determinant models between the variables green grains (GR), grain yield $(\mathrm{GY})$, total grain protein (PG) and total oil (OT) for the evaluated characters. Giruá, Rio Grande do Sul State, Brazil.

\begin{tabular}{ccccccccc}
\hline \multicolumn{7}{c}{ Predictive and determinant models } \\
\hline VARIABLES & GR & \multicolumn{2}{c}{ GY } & \multicolumn{3}{c}{ PG } \\
\hline Intercept & $-347,5432$ & INTERCEPT & 0,00 & INTERCEPT & $326.036,0000$ & INTERCEPT & 7,9025 \\
MS & $-0,5026$ & PO & 0,00 & PH & $-0,0350$ & FI & $-0,0413$ \\
PO & 4,3489 & GM & 261,42 & MS & $-0,0790$ & PTW & 0,0475 \\
GP & $-0,0860$ & MT & 0,0001 & PTH & $-0,0217$ & PF & 0,1329 \\
NT & $-4,2342$ & & & PP & 0,0198 & NT & 0,0056 \\
MT & 36,0280 & & & FT & $-0,5060$ & FT & 0,3222 \\
CH & 23,9290 & & & OT & 2,1973 & DN & $-0,1729$ \\
AT & $-25,6108$ & & & IG & 3,2442 & OT & 3,7017 \\
PT & $-47,3590$ & & & KT & 5,5797 & NT & $-2,5629$ \\
KT & $-104,9242$ & & & OT & $-0,1043$ & KT & 2,5676 \\
PG & 0,0993 & & & FG & 0,1071 & PM & $-0,0202$ \\
MM & 46,4549 & & & PM & $-0,4101$ & NO & 0,525 \\
\hline
\end{tabular}

Number of pods on the main stem (MS), Number of pods with one grain (PO), Number of grains per plant (GP), First pod insertion height (FI), Total protein (NT), Mineral material (MT), Total Carbohydrates (CH), Total Calcium (AT), Total Phosphorus (PT), Total Potassium (KT), Mineral Matter in Grain (MM), Plant Grain Mass (GM), Plant Height $(\mathrm{PH})$, Fiber in acid detergent (FT), total oil (OT), crude grain fiber (FG), palmitic acid (PM), number of pods with two grains $(\mathrm{PTH})$, number of pods with four grains $(\mathrm{PF})$, neutral detergent fiber (DN), linoleic acid (NO).

The components of variance and genetic parameters (REML) were estimated for major components of grain quality for seven soybean cultivars (Table 6). The phenotypic expression of the character is mainly related to the effects of the environment, and another part of the genetic variation present. Therefore, we sought to evidence a relationship between individual phenotypic variance $\left(\sigma^{2} P\right)$ and genotypic variance $\left(\sigma^{2} G\right)$, where it was possible to identify that for Grain Yield (GY), Number of green grains (GR), Total oil (OT), Crude fiber in the grain (FG), Mineral material (MT), Palmitic acid (PM), Stearic acid (ES), Oleic acid (LE), Linoleic acid (NO), Linolenic acid (NC) and Total protein (PT) ) were determined by 33\%, 36\%, 0\%, 33\%, 10\%, 42\%, 100\%, 75\%, $78 \%, 53 \%$ and $85 \%$ for genetic effects respectively. To relate the phenotypic variance with the interaction between the covers, that is, to identify how much the environment influenced the variables studied, it was identified that $18 \%, 93 \%, 68 \%, 33 \%, 0 \%, 34 \%, 0 \%, 8 \%, 14 \%, 24 \%$ and $2 \%$ are influenced by the environment respectively. 
Table 6. Genetic effect on the main characters of the grains. Giruá, Rio Grande do Sul State, Brazil.

\begin{tabular}{|c|c|c|c|c|c|c|}
\hline \multirow{2}{*}{$\begin{array}{l}\text { REML variance } \\
\text { components }^{1}\end{array}$} & \multicolumn{6}{|c|}{ Characters $^{2}$} \\
\hline & GY & GR & OT & FG & MT & PM \\
\hline $\mathrm{Vg}$ & 312,80 & 69,33 & 0,00 & 0,01 & 0,01 & 0,30 \\
\hline Vint & 175,82 & 81,74 & 0,37 & 0,01 & 0,00 & 0,24 \\
\hline $\mathrm{Ve}$ & 458,78 & 38,00 & 0,17 & 0,01 & 0,00 & 0,15 \\
\hline $\mathrm{Vp}$ & 947,41 & 189,08 & 0,54 & 0,03 & 0,01 & 0,70 \\
\hline h2g & 0,33 & 0,37 & 0,00 & 0,26 & 0,96 & 0,44 \\
\hline h2mg & 0,66 & 0,59 & 0,01 & 0,54 & 0,99 & 0,68 \\
\hline Acgen & 0,81 & 0,77 & 0,10 & 0,74 & 0,99 & 0,82 \\
\hline c2int & 0,19 & 0,43 & 0,68 & 0,29 & 0,01 & 0,34 \\
\hline Rgloc & 0,64 & 0,46 & 0,01 & 0,47 & 0,99 & 0,56 \\
\hline CVgi\% & 15,36 & 19,23 & 0,23 & 1,57 & 1,68 & 5,00 \\
\hline $\mathrm{CVe} \%$ & 18,60 & 14,23 & 1,98 & 2,04 & 0,28 & 3,56 \\
\hline Overall mean & 3,64 & 43,31 & 21,13 & 5,33 & 5,21 & 11,03 \\
\hline REML variance & \multicolumn{6}{|c|}{ Characters $^{2}$} \\
\hline components $^{1}$ & ES & LE & NO & $\mathrm{NC}$ & PT & \\
\hline$\sigma^{2} G$ & 0,03 & 2,99 & 4,02 & 0,86 & 1,27 & \\
\hline$\sigma^{2} I N T$ & 0,00 & 0,34 & 0,72 & 0,39 & 0,03 & \\
\hline$\sigma^{2} E$ & 0,00 & 0,64 & 0,40 & 0,37 & 0,19 & \\
\hline$\sigma^{2} P$ & 0,03 & 3,97 & 5,14 & 1,61 & 1,49 & \\
\hline$\hat{H}^{2} g$ & 0,82 & 0,75 & 0,78 & 0,53 & 0,85 & \\
\hline$\hat{H}^{2} m g$ & 0,94 & 0,91 & 0,90 & 0,77 & 0,95 & \\
\hline Acgen & 0,97 & 0,96 & 0,95 & 0,88 & 0,98 & \\
\hline$C^{2} I N T$ & 0,07 & 0,09 & 0,14 & 0,24 & 0,02 & \\
\hline rgloc & 0,92 & 0,90 & 0,85 & 0,69 & 0,97 & \\
\hline CVgi\% & 3,66 & 6,77 & 3,66 & 19,44 & 2,90 & \\
\hline $\mathrm{CVe} \%$ & 1,38 & 3,13 & 1,15 & 12,67 & 1,12 & \\
\hline Overall mean & 4,52 & 25,53 & 54,79 & 4,78 & 38,80 & \\
\hline
\end{tabular}

${ }^{1} \sigma^{2} G$ : genotypic variance; $\sigma^{2} I N T$ : variance of genotype x environment interaction; $\sigma^{2} E$ : residual variance; $\sigma^{2} P$ : individual phenotypic variance; $\hat{H}^{2} g$ : broad sense heritability for total genotypic effects; $\hat{H}^{2} m g$ : heritability of the genotype mean; $\check{r} g \check{g}$ : accuracy for genotype selection; $C^{2} I N T$ : coefficient of determination of the effects of genotype $\mathrm{x}$ environment interaction; $\check{r} g$ loc: genotypic correlation between the performance of environments; $C V g(\%)$ : genotypic coefficient of variation; $\mathrm{CVe}(\%)$ : residual coefficient of variation; Overall mean: overall mean of the experiment. ${ }^{2}$ Total grain yield (GY), Number of green grains (GR), Total oil (OT), Crude grain fiber (FG), Mineral material (MT), Palmitic acid (PM), Stearic acid (ES), Oleic acid (LE), Linoleic acid (NO), Linolenic acid (NC), Total phosphorus (PT). 
Analyzing the contribution of genotypic variation for genotypes $\mathrm{x}$ environments interaction $\left(C^{2} I N T\right)$, for GY $(56 \%)$, is the influence of the genotype, that is, the cultivar, the remaining $44 \%$ is the result of the coverages used. For the other variables, they present the following interactions, FG (100\%), PM (80\%), LE (11\%), NO (17\%), NC (45\%) and PT (2\%).

Heritability demonstrates the genetic variance existing in the phenotypic variance, in addition to indicating the experimental precision and reliability of the phenotype (CARVALHO 2017). The broad sense heritability $\left(\widehat{H}^{2} g\right)$ considers the total genotypic effects, without considering the environment genotype interaction and the average genotype heritability $\left(\widehat{H}^{2} m g\right)$, demonstrates the variation of the plant's genetics influenced by environmental and genetic factors. For GY, broad sense heritability $\left(\widehat{H}^{2} g\right), 33 \%$ is a genetic effect and $67 \%$ is an effect of the environment. The LV shows broad sense heritability $\left(\widehat{H}^{2} g\right)$ of $37 \%$, being a genetic effect and $63 \%$ influenced by environmental factors. For the characters MT (96\%), ES (82\%), LE (75\%), NO (78\%), NC (53\%), and PT $(85 \%)$, present high values of broad sense heritability $\left(\widehat{H}^{2} g\right)$, that is, they are more influenced by genetics than environment. The characters FG (26\%), PM (44\%), have a high influence of the environment $74 \%, 56 \%$ respectively. When compared with the mean heritability $\left(\widehat{H}^{2} \mathrm{mg}\right)$ of the genotype, for all variables analyzed, there is an increase with greater magnitude due to the removal of residual effects resulting from the interaction.

The genotypic correlation between the performance of environments (r̆gloc) for the characters MT (0.99), ES (0.92), LE (0.90), NO (0.85) and PT (0.97), showed high results $(0.70$ $<$ r̆gloc) with greater participation of simple interaction (CARVALHO et al., 2017). Low correlation

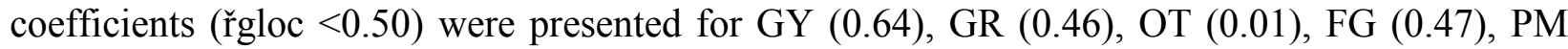
(0.56). Where it indicates greater effects of interaction with complex nature, and results in less phenotypic stability of the genotypes (CARVALHO et al., 2018).

According to the graph of multivariate analysis of the main components (BIPLOT), where it explains $47.6 \%$ of the collected data (Figure 2), in this way to grow DM 5958 IPRO, in the coverage of Avena sativa, presented greater contribution to the variables number of pods with three grains $(\mathrm{PTH})$, number of pods per plant $(\mathrm{PP})$, grain yield (GY), number of branches $(\mathrm{NB})$, number of grains per plant (GP) and grain mass of the plant (GM). 


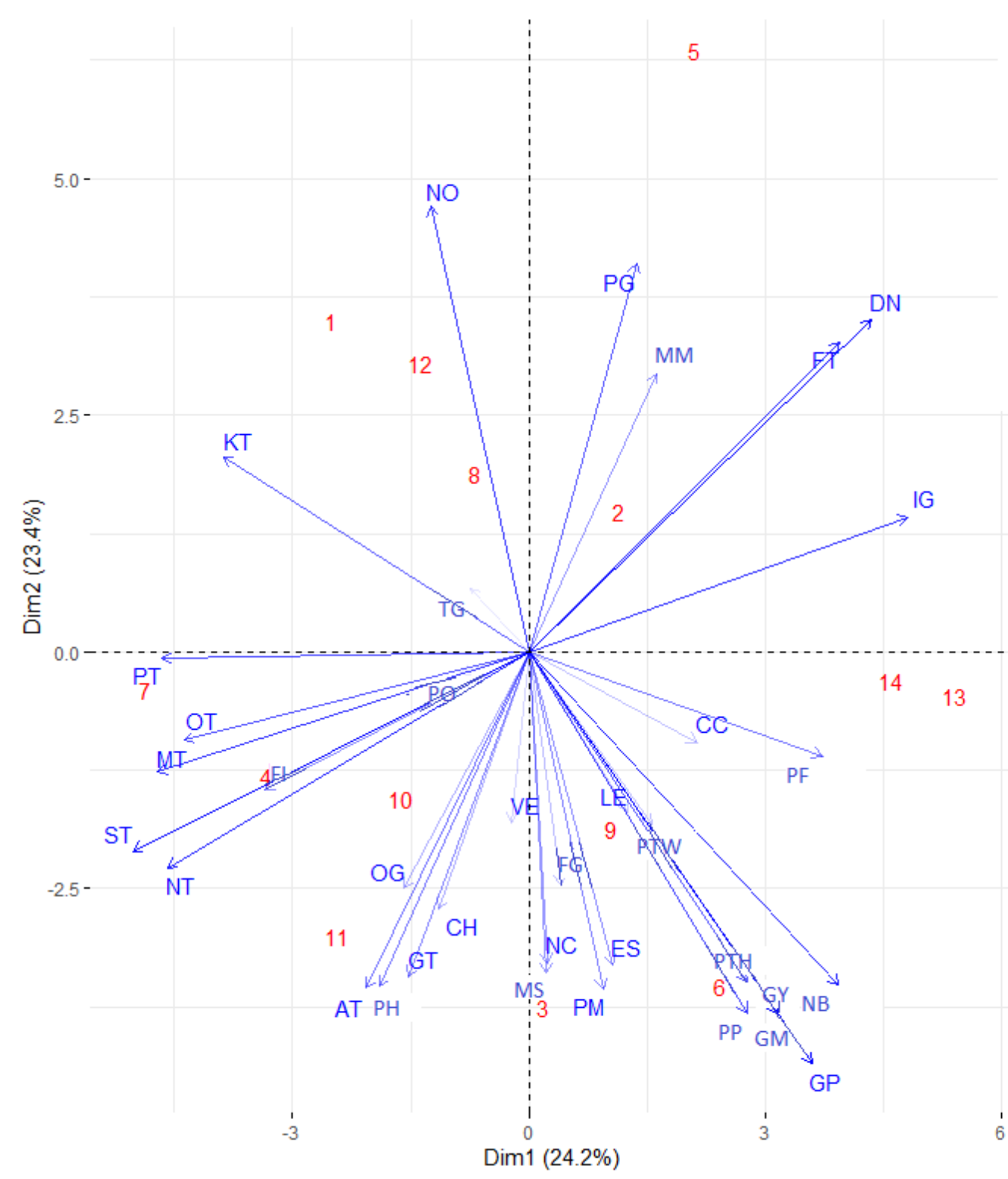

Figure 2. Multivariate analysis of main components (BIPLOT). Giruá, Rio Grande do Sul State, Brazil. Avena sativa: 1859 (1), Avena sativa: 2570 (2), Avena sativa: 5838 (3), Avena sativa: 5947 (4), Avena sativa: 5851 (5), Avena sativa: 5958 (6), Avena sativa: 57 I52 (7) Raphanus sativus + Avena strigosa: 1859 (8), Raphanus sativus + Avena strigosa: 2570 (9), Raphanus sativus + Avena strigosa: 5838 (10), Raphanus sativus + Avena strigosa: 5947 (11), Raphanus sativus + Avena strigosa: 5951 (12) Raphanus sativus + Avena strigosa: 5958 (13), Raphanus sativus + Avena strigosa: 57 I52 (14).

The variables number of pods with three grains (PTH), number of pods per plant (PP), grain yield (GY), number of branches (NB), number of grains per plant (GP) and grain mass of the plant (GM) presented greater contribution, due to the fact that for this cultivar, it presented a low plant 
stand, in which it maximized ramifications and number of pods, consequently increasing the other components mentioned above. The cultivar C2570 RR with coverage of Raphanus sativus + Avena sativa, represented greater affinity for oleic acid (LE), but negatively representing the content of this acid in the seed. The cultivar FPS 1859 RR showed affinity for the highest levels of linoleic acid regardless of the coverage used and the cultivar SRM 5951 for the coverage of Raphanus sativus + Avena strigosa. In the industrial process, it is sought to produce soy oil with greater production stability, with higher levels of oleic acid, and lower levels of linoleic and linolenic acids (BUENO et al., 2017). The coverage of Avena sativa with the cultivar M5838 IPRO, showed interaction for the variables number of pods on the main stem (MS), due to the fact that it had lower plant height and smaller branches, thus concentrating a greater number of pods on the main stem of the plant.

For the cultivar M5947 IPRO in the cover with Raphanus sativus + Avena strigosa, it had an affinity for the plant height $(\mathrm{PH})$ variables, which may be related to nutrient cycling from the cover used, in which all cultivars showed higher averages when compared to cover of Avena sativa. For the same coverage to grow M5838 IPRO, it showed greater affinity for total oil in the grain (OG). Because it is a characteristic of soybeans to have high levels of oil in the grain (20\%) and other chemical components, its composition is mainly influenced by climatic conditions and genetic conditions of cultivars (SALES et al., 2016).

The cultivar M5947 IPRO, on the cover of Avena sativa, showed affinity for the first pod insertion height, with $19.66 \mathrm{~cm}$ (Table 2). This is a characteristic that is not desired, according to studies carried out, the optimum first pod insertion height is $15 \mathrm{~cm}$. The same cultivar showed higher plant height, which can cause lodging and a reduction in the growing area (SZARESKI et al., 2016). The cultivar C2570 RR, on the cover of Avena sativa showed greater affinity for the mineral matter in the grain (MM), soy is rich in minerals, which are in the form of micronutrients and macronutrients, aiming at the use in human and animal food, paramount importance is the increase of these minerals aiming at better product quality (BRUNINI et al., 2016).

\section{CONCLUSION}

The different coverings influenced the soybean performance for the main variables studied, being as follows the first pod insertion, the number of branches, the pods with three grains, the pods per plant, the grains per plant, green grains and the total oil in the grain. 
Grain yield was maximized in the coverage of Raphanus sativus + Avena strigosa for the cultivar DM 57I52 IPRO, and the greenish grain levels were lower, consequently increasing the percentage of oil content for that same coverage.

The components of variance and genetic parameters show that grain yield was influenced by $56 \%$ due to the effects of cultivars and $44 \%$ coming from the soil cover used.

\section{REFERENCES}

ALBRECHT, L.P.; BRACCINI, A. D. L.; ÁVILA, M. R.; SUZUKI, L. S.; SCAPIM, C. A.; BARBOSA, M. C. 2008. Teores de óleo, proteínas e produtividade de soja em função da antecipação da semeadura na região oeste do Paraná. Bragantia, Campinas, v.67, n.4, p.865873. https://doi.org/10.1590/S0006-87052008000400008

ARRUDA, M. H. M., MENEGHELLO, G. E., VIEIRA, J. F., GADOTTI, G. I. 2017. Qualidade fisiológica de lotes de sementes de soja com diferentes percentuais de sementes esverdeadas. Magistra, Bahia, 28(2), 194-200.

BRUNINI, M. A.; BARROS, M. A.; PEREIRA, M.; CERQUEIRA, J. B.; MENEZES, P. T. R.; FURTADO, I. R. 2016. Qualidade de grãos de onze cultivares de soja. Nucleus Animalium, São Paulo, v. 8, n. 2, p. 8.

BUENO, R. D.; SILVA, L. C. C.; FERREIRA, F.T.; BERNARDELI, A.; PIOVESAN, N. D.; DAL-BIANCO, M. 2017. Melhoramento genético visando qualidade do grão de soja. Colhendo as safras do conhecimento, Espírito Santo, p. 225.

CARVALHO, I. R.; NARDINO, M.; DEMARI, G.; PELEGRIN, A. J.; FERRARI, M.; SZARESKI, V. J.; OLIVEIRA, V. F.; BARBOSA, M. H.; SOUZA, V. Q.; OLIVEIRA, A. C.; MAIA, L. 2017. Components of variance and inter-relation of important traits for maize (Zea mays) breeding. Aust. J. Crop. Sci., Austrália, v. 11, p. 982-988. Doi: 10.21475/ajcs.17.11.08. Pne474

CARVALHO, I. R.; NARDINO, M.; SOUZA, V.Q. 2017. Melhoramento e cultivo da soja. Porto Alegre: Cidadela, 248p.

CARVALHO, I. R.; SZARESKI, V. J.; MAMBRIN, R. B.; FERRARI, M; PELEGRIN, A. J.; CORAZZA, T.; PETER, M.; SILVEIRA, D. C.; CONTE, G. G.; BARBOSA, M. H.; SOUZA, V. Q. 2018. Biometric models and maize genetic breeding. Aust. J. Crop. Sci., Australia, v. 12, p. 1796-1805.

CiBOTTO, D. V., NETO, A. M. O., GUERRA, N., MEERT, L., BOTTEGA, E. L., LEAL, G. B. 2016. Produtividade da soja com antecipação da adubação potássica nas culturas da aveia preta, canola e trigo. Campo Digital, Paraná, v. 11, n. 1.

CONAB - Companhia Nacional de Abastecimento, 2020: Acompanhamento da safra brasileira: Grãos, nono levantamento, jun. 2020, safra 2019/2020.

ESCALERA, V. R. A.; PIMENTEL, J. R.; TROYJACK, C.; CARVALHO, I. R.; SZARESKI, V. J.; JAQUES, L. A.; CONTE, G. G.; VILlELA, F. A.; AUMONDE, T. Z.; PEDO, T. 2019. Physiological Quality of Rice and Soybean Seeds Produced Under Hydric Stress in Greenhouse. Journal of Agricultural Science, Canadá, v. 11, p. 22. https://doi.org/10.5539/jas.v11n12p22

FERREIRA, C. D.; ZIEGLER, V.; GOEBEL, J. T. S.; HOFFMANN, J. F.; CARVALHO, I. R.; CHAVES, F. C.; OLIVEIRA, M. 2019. Changes in phenolic acids and isoflavone contents 
during soybean drying and storage. Journal of Agricultural and Food Chemistry, Washington, p. 1-38. https://doi.org/10.1021/acs.jafc.8b06808

FOLLMANN, D. N.; SOUZA, V. Q.; CARGNELUTTI FILHO, A.; NARDINO, M.; CARVALHO, I. R.; DEMARI, G.; MEIRA, D.; SILVA, A. D. B.; MEIER, C. 2016. Agronomic performance and stability of soybean cultivars in not preferred time. International Journal of Current Research, Amsterdam, v. 08, p. 37665-37670.

GIACOMINI, S. J.; AITA, C.; VENDRUSCOLO, E.R.O.; CUBILLA, M.; NICOLOSO, R. R.; FRIES, M. R. 2003. Matéria seca, relação C/N e acúmulo de nitrogênio, fósforo e potássio em misturas de plantas de cobertura de solo. Revista Brasileira de Ciência do Solo, Minas Gerais, 27:325-334. http://dx.doi.org/10.1590/S0100-06832003000200012

MEIRA, D.; CARVALHO, I.R.; NARDINO, M.; FOLLMANN, D. N.; PELEGRIN, A. J.; SZARESKI, V. J.; FERRARI, M.; OLIVOTO, T.; MEIER, C.; SOUZA, V. Q. 2016. Path analysis and dissimilarity in soybean with indeterminate habit. International Journal of Current Research, Amsterdam, v. 8, p. 39568-39573.

MÉDIÈNE, S., VALANTIN-MORISON, M., SARTHOU, J. P., DE TOURDONNET, S., GOSME, M., BERTRAND, M., PELOSI, C. 2011. Agroecosystem management and biotic interactions: a review. Agronomy for sustainable development, França, 31(3), 491-514. https://doi.org/10.1007/s13593-011-0009-1

PEREIRA, R. A.; ALVES, P. L. C. A.; CORRÊA, M. P.; DIAS, T. C. S. 2011. Influência da cobertura de aveia preta e milheto sobre comunidade de plantas daninhas e produção de soja.

Revista Brasileira de Ciências Agrárias, Recife, Brasil, v.6, n.1, p.1 - 10. http://dx.doi.org/10.5039/agraria.v6i1a545

SALES, V. H. G.; PELUZIO, J. M.; AFFÉRRI, F. S.; OLIVEIRA JUNIOR, W. P.; SALES, P. V. G. 2016. Teor de óleo e proteína em grãos de soja em diferentes posições da planta. Revista Agro Ambiente, Roraima, v. 10, n. 1, p. 22-29. http://dx.doi.org/10.18227/19828470ragro.v10i1.2462

SANTOS, H. G.; JACOMINE, P. K. T.; DOS ANJOS, L. H. C.; DE OLIVEIRA, V. A.; LUMBRERAS, J. F.; COELHO, M. R.; CUNHA, T. 2006. Sistema brasileiro de classificação de solos. 2 eds. Rio de Janeiro: Embrapa Solos, 306p.

STROBEL, T.; KOCH, F.; AISENBERG, G. R.; SZARESKI, V. J.; CARVALHO, I.R.; NARDINO, M.; SOUZA, V. Q.; VILLELA, F. A.; PEDO, T.; AUMONDE, T. Z. 2016. Physical and physiological quality of soybean seeds harvested under different trial systems after storage period. Australian Journal of Basic and Applied Sciences, Australia, v. 10, p. 124-130, 2016.

SZARESKI, V. J.; ZANATTA, E.; KOCH, F.; AISENBERG, G. R.; DEMARI, G.; KEHL, K.; PIMENTEL, J. R.; CARVALHO, I. R.; NARDINO, M.; TROMBETA, H. W.; SOUZA, V. Q.; MARTINAZZO, E. G.; PEDO, T.; AUMONDE, T. Z. 2016. Pre-harvest desiccation and seed production in soybean crops. International Journal of Current Research, Amsterdam, v. 8, p. 41534-41537.

SZARESKI, V. J.; CARVALHO, I.R.; DEMARI, G.; PELISSARI, G.; PELEGRIN, A. J.; BARBOSA, M. H.; CORAZZA, T.; SANTOS, N. L.; MARTINS, T.; NARDINO, M.; PEDO, T.; SOUZA, V. Q.; AUMONDE, T. Z. 2018. Path analysis of agronomic traits in soybean cultivars with determinate and indeterminate growing habits. Aust. J. Crop. Sci., Australia, v. 12, p. 531-538. Doi: 10.21475/ajcs.18.12.04.pne608

TAVARES, L.C.; RUFINO, C. D. A.; BRUNES, A. P.; TUNES, L. M. D.; BARROS, A. C. S. A.; PESKE, S. T. 2013. Desempenho de sementes de soja sob deficiência hídrica: rendimento e 
qualidade fisiológica da geração F1. Ciência Rural, Santa Maria, 43, 1357-1363. http://dx.doi.org/10.1590/S0103-84782013000800003

ZANON, A. J.; SILVA, M. R.; TAGLIAPIETRA, E. L.; CERA, J. C.; BEXAIRA, K, P.; RICHTER, G. L.; JUNIOR, A. J. D.; ROCHA, T. D. M.; WEBER, P. S.; STRECK, N. A. 2018. Ecofisiologia da Soja Visando Altas Produtividades. Ed, v. 1, p. 136. 